\title{
Effect of seasons on productive performance, metabolic changes and immunity response in rabbits
}

\author{
E. M., Abdel-Kafy', Z.A. Yasmein ${ }^{1}$, I. El Wardany ${ }^{3}$, S. F. Darwish ${ }^{2}$ \& Marwa S. Abdo \\ ${ }^{1}$ Animal Production Research Institute, Agricultural Research Center, Dokki, Giza, Egypt \\ ${ }^{2}$ Biotechnology Research Unit Animal Reproduction Research Institute, Agricultural Research Center, El Ahram \\ , Giza, Egypt \\ ${ }^{3}$ Department of Poultry Production, Faculty of Agriculture, Ain Shams University,Egypt \\ Corresponding author: Jasmein2004@hotmail.com
}

\begin{abstract}
The present study was carried out to investigate the effect of season on growth performance traits, metabolite assays and gene expression for innate immune in response to vaccination against pasteurellosis. APRI line, weaned females rabbits of were used in this study a local population. Rabbits weaned at 35 days and introduced in the experiment. Weight at 5 weeks considered as the beginning and all rabbits were weighed every 7 days until 12 weeks old. The feed consumption measured at the same weekly interval. Immunity response was studied by vaccination with Pasteurella multocida at 8 and 10 weeks of age as challenge experiment and the blood samples taken at 8,10 and 12 weeks of age. Gene expressions for interleukin-6 (IL-6) and toll-like receptor-4 (TLR-4) were assayed by Real Time-PCR. Metabolite assays included glucose, triglycerides, and urea nitrogen and blood samples were taken at 8,10 and 12 weeks of age, respectively. The body weights in winter at W5, W8and W12 of age were higher than those in other seasons. Season had significant $(\mathrm{P}<0.05)$ influence on daily gain and feed intake. Triglycerides were significantly higher $(\mathrm{P}<0.05)$ in rabbits during summer. From summer to spring season, the urea values gradually increased significant in rabbits. Vaccination with Pasteurella multocida led to an increase in expression for IL-6 in autumn and winter. Expression for IL-6 in spring was lowest the values. Gene expression of TLR4 in rabbits under different seasons had not significantly different. With vaccination by Pasteurella multocida, it is recommended by using additives to enhance immunity during summer and spring in rabbit.
\end{abstract}

Keywords: rabbit, season, gene expression, immunity, metabolic changes, growth

\section{Introduction}

Domestic rabbits have been considered as one of several alternative species quite suitable source of animal protein in the developing countries (Hanaa et $a l ., 2014)$. Moreover, the rabbit has the capacity to convert both high concentrate feeds and roughage with increased efficiency when compared with large animal species (Hassan et al., 1994). Study of genetic and nongenetic factors affecting on productive traits in rabbits is important issue in order to reach highest rates in commercial production (El-Sabrout et al., 2014).There is a strong link between stress and immune systems (Mann, 2003). The immune and metabolic rate of fattening rabbits could be affected by environmental stress (Moscati et al. 2008, Amici et al., 1998). On the other hand, routine vaccination against pasteurellosis is performed in most rabbit farms despite environmental stress. The prevention is based only on certain technical aspects of hygiene despite environmental conditions and their effects on immunity response in rabbit that may cause vaccination difficult (Kulcsár et al., 2008). With climate changes in the last two decades, the growth performances in rabbits need for updating. Also, Limited data are available about immunity response and metabolite assays in rabbit under different seasons. So, our trial is to study the growth performance traits and metabolic changes and to investigate the gene expression for innate immunity in response to vaccination by Pasteurellosis under different seasons.

\section{Materials and methods}

Atotal number of 384 young rabbits used in this study were born from July 2015 to June 2016, from females of APRI line local population raised in Rabbits Farm of Sakha Station, Animal Production Research Institute, Agriculture Research Center, Egypt. Indoor ambient temperature and relative humidity throughout the experimental period were in summer $28.98^{\circ} \mathrm{C}$ and $55.3 \%$, in autumn $20.99^{\circ} \mathrm{C}$ and $63.7 \%$, in winter $16.0^{\circ} \mathrm{C}$ and $60.4 \%$ and in spring were $24.62^{\circ} \mathrm{C}$ and $51.8 \%$., respectively. All rabbits were weaned at 35 days and introduced in the experiment and the females and males were equal. Weighed at 5 weeks and considered as the beginning Weight, all rabbits were weighed every 7 days until 12 weeks old. The feed consumption measured at the same previously intervals. Pelleted feed was provided ad-libitum and water was always available through automatic nipple drinkers in each wire mesh cage. The chemical analysis of pelleted feed was dry matter $89.6 \%$, protein $16.1 \%$, crude fiber $11.7 \%$ and minerals $7.0 \%$. Cages with one rabbit was placed in the experimental building and the ventilation and temperature were natural.

At the day of blood sampling, feeders were closed at 09:00 h. Post-absorption and after 4 to $6 \mathrm{~h}$ of feeding 
blood sample were randomly collected in 8, 10 and 12 weeks of age from the 30 animals per season. Blood samples were withdrawn from the ear vein into syringes containing EDTA. Blood was centrifuged at $3000 \mathrm{~g}$ for $15 \mathrm{~min}$. to get plasma stored at $-20^{\circ} \mathrm{C}$ until assayed parameters of the metabolites. Metabolite assays included glucose, triglycerides, and urea nitrogen. The glucose was assayed by glucose colorimetric detection kit (BioMed- diagnostic). Triglycerides and urea nitrogen concentrations were analysed using enzymatic colorimetric assays from (BioMed- diagnostic) according to Vassault, 1986.

Immunity response was studied by vaccination with Pasteurella multocida (P.m.).In challenge experiment used 80 rabbits APRI line $(n=20$ each season). Rabbits at 8 weeks of age was vaccinated $(\mathrm{n}=10)$ as treated group and rabbits treated by saline solution $(n=10)$ as control group. Vaccination and treatment by saline were repeated once at 2 weeks interval (at 10 weeks). Blood samples were taken from two groups at 8 (first vaccination and treatment), 10 (after 2 weeks from first vaccination and treatment) and 12 weeks (after 2 weeks from second vaccination and treatment). Seventy two rabbits were killed at 8 , 10 and 12 weeks from vaccinated and unvaccinated groups (3 rabbit / time /group) to remove the spleen.

\section{Real Time-PCR}

Gene expression for IL-6 and TLR-4 were assayed by Real Time-PCR. RNA was extracted from spleen and for purification used RNeasy Mini Kit. Quantitect SYBR green kit used in Real Time PCR. Sequences of oligonucleotide primers and probes were used in Real Time-PCR shown in table 1. Real time PCR machine was used Stratagene MX3005P. Cycling conditions for Real Time-PCR according to Quantitect SYBR green PCR kits shown in table 2. Amplification curves and ct values were determined by the stratagene MX3005P software. To estimate the variation of gene expression on the RNA of the different samples, the CT of each sample was compared with that of the control group according to the " $\Delta \Delta \mathrm{Ct}$ " method stated by Yuan et al., 2006.

\section{Statistical analysis}

For body weight, growth, feed intake and all the parameters taken in account were analyzed using the general linear models procedure of SAS (1999). The model $\mathrm{Yij}=\mu+\mathrm{Si}+\mathrm{Xj}+\mathrm{eijk}$ included $\mu=$ the overall mean, $\mathrm{Si}=$ effect of season $\mathrm{i}=1,2,3$ and $4, \mathrm{Xj}=$ effect of sex $\mathrm{j}=1$ and 2 , eijk= residual error term. Effect of sex ignore in the results and focusing on season effect. Duncan test was used to detect significant differences.

\section{Results}

\section{Body weights}

Body weights $(\mathrm{g})$ in winter at W5, W8, W10 and W12 of age were higher than those in other seasons
(Table 3). The high body weight at 5 week of age observed in summer may be explained mainly by the fact that all rabbits weaned during this period were born from females had low weaning survival corroborated with findings of DalleZotte and Paci (2013). They reported that due to the lower litter size of pups born in summer and autumn, their individual weight at weaning were higher than those of pups born in winter $(\mathrm{p}<0.001)$.

The season effect was studied on the daily gain and feed intakes observed for the whole population between 5 and 12 weeks of age (Table 4). Season had a significant $(\mathrm{P} \leq 0.05)$ influence on daily gain $(\mathrm{g})$ and feed intake (Table 4). The low growth rate observed in summer may be explained mainly by decline in feed intake regularly with the increase of temperature during fattening Table 4. This late type of effect of environmental temperatures was in good agreement with the observation of pervious authors (Poujardieu and Matheron, 1984).Feed conversion in winter was the best comparing with those in others seasons but not significantly (Table 4).

\section{Metabolic changes}

The plasma profiles of glucose, triglycerides and urea during all season in rabbits are shown in Table 5. Mean plasma glucose concentrations were not significantly different as affected by season. Triglycerides were higher $(\mathrm{P}<0.05)$ in rabbits during summer (Table 5). From summer to spring season, urea values gradually significant increased in rabbits (Table 5). These results are similar to those of Ayoub et al. (2007) and Okab et al., 2008 on rabbits. They attributed these changes to variations in thyroidal activity at different seasons, as exposure to low environmental temperature stimulates the secretion of thyroxine. Thyroid hormones stimulate cholesterol synthesis as well as the hepatic mechanisms that play a central role in regulating fat metabolism (Reddy and Rao 2006). Under normal conditions fatty acids release from adipose tissues far exceeds the rate of fat oxidation, but the excess fatty acids provide a readily available substrate to enable a rapid increase in fat oxidation when required (Romijn et al., 1995). The total amount of free fatty acids that can be transported in the plasma is limited because free fatty acids are insoluble and must be transported bound to albumin (Yki-Järvinen, 2010). Secretion of fatty acids as triglycerides therefore serves as an additional potential energy source in the form of circulating lipids (Tuvdendorj et al., 2015).

\section{Immunity response}

Vaccination with Pasteurella multocida (P.m.) led to an increase in gene expression for Interleukin-6 (IL6) an up regulation (1.0 to 0.78 fold) of compared to the uninfected (UI) control in autumn and winter (Figure 1) while expression for IL-6 in spring was 
lowest the values ( 0.42 fold $)$ as shown in Figure 1 . The gene expression for IL-6 in season times of vaccination with Pasteurella multocida (P.m.) revealed a substantial increase in proinflammatory cytokines and an early antimicrobial response as compared to uninfected (UI) control (Schnupf and Sansonetti 2012).

Gene expression of toll-like receptor-4 (TLR-4) in rabbits under different seasons had not significantly different (Figure 2). During the process of intestinal inflammation, intestinal epithelial cells could positively respond to pathogen associated molecular patterns via toll-like receptor (TLRs), which Toll-like receptors (TLRs) belong to the innate immune system and are a major class of pattern recognition receptors representing the first line of the innate immune response (Abrantes et al., 2013). Our results may be due the TLR-4 plays a critical role to regulate inflammatory responses against common bacteria and food antigens (Kajikawa et al., 2005) and the rabbit under same condition during different seasons.

It is summarized that winter and spring had a positive effect on body weight, daily gain $(\mathrm{g})$ and feed intakes. Gene expression of toll-like receptor-4 (TLR4) in rabbits under different seasons had not significantly different. Vaccination with Pasteurella multocida (P.m.) led to an increase in expression for interleukin-6 in autumn and winter. It is suggested to use additives for enhancing immunity during summer and spring.

Table 1. Sequences of oligonucleotide primers and probes were used in SYBR Green Real Time-PCR.

\begin{tabular}{|c|c|c|}
\hline Gene & Primer sequence $\left(5^{\prime}-3^{\prime}\right)$ & Reference \\
\hline \multirow{2}{*}{ GAPDH } & TGACGACATCAAGAAGGTGGTG & \multirow[t]{4}{*}{ Schnupf and Sansonetti, 2012} \\
\hline & GAAGGTGGAGGAGTGGGTGTC & \\
\hline \multirow{2}{*}{ IL6 } & CTACCGCTTTCCCCACTTCAG & \\
\hline & TCCTCAGCTCCTTGATGGTCTC & \\
\hline \multirow{2}{*}{ TR4 } & GAGCACCTGGACCTTTCAAATAAC' & \multirow[t]{2}{*}{ Kajikawa et al., 2005} \\
\hline & GAACTTCTAAACCACTCAGCCCTTG & \\
\hline
\end{tabular}

Table 2. Cycling conditions for SYBR green in Real time PCR.

\begin{tabular}{c|c|ccc|ccc}
\hline \multirow{2}{*}{$\begin{array}{c}\text { Reverse } \\
\text { transcription }\end{array}$} & $\begin{array}{c}\text { Primary } \\
\text { denaturation }\end{array}$ & \multicolumn{2}{|c|}{ Amplification $(40$ cycles $)$} & \multicolumn{2}{c}{ Dissociation curve $(1$ cycle) } \\
\cline { 3 - 7 } & $\begin{array}{c}\text { Secondary } \\
\text { denaturation }\end{array}$ & $\begin{array}{c}\text { Annealing } \\
(\text { Optics on })\end{array}$ & Extension & $\begin{array}{c}\text { Secondary } \\
\text { denaturation }\end{array}$ & Annealing & $\begin{array}{c}\text { Final } \\
\text { denaturation }\end{array}$ \\
\hline $50^{\circ} \mathrm{C}$ & $94^{\circ} \mathrm{C}$ & $94^{\circ} \mathrm{C}$ & $60^{\circ} \mathrm{C}$ & $72^{\circ} \mathrm{C}$ & $94^{\circ} \mathrm{C}$ & $60^{\circ} \mathrm{C}$ & $94^{\circ} \mathrm{C}$ \\
$30 \mathrm{~min}$. & $5 \mathrm{~min}$. & $15 \mathrm{sec}$. & $30 \mathrm{sec}$. & $30 \mathrm{sec}$. & $1 \mathrm{~min}$. & $1 \mathrm{~min}$. & $1 \mathrm{~min}$. \\
\hline
\end{tabular}

Table 3. Body weights ( $\mathrm{g}$ ) in growing rabbits as affected by seasons (Means $\pm \mathrm{SE}$ ).

\begin{tabular}{ccccc} 
Season & W5 & W8 & W10 & W12 \\
\hline Summer & $578.7^{\mathrm{a}} \pm 12.5$ & $1011.5^{\mathrm{ab}} \pm 27.4$ & $1277.9^{\mathrm{b}} \pm 39.8$ & $1541.8^{\mathrm{b}} \pm 56.2$ \\
Autumn & $519.7^{\mathrm{b}} \pm 13.2$ & $929.2^{\mathrm{b}} \pm 33.5$ & $1222.3^{\mathrm{b}} \pm 49.9$ & $1582.2^{\mathrm{b}} \pm 64.4$ \\
Winter & $581.2^{\mathrm{a}} \pm 14.1$ & $1074.8^{\mathrm{a}} \pm 43.1$ & $1450.2^{\mathrm{a}} \pm 56.9$ & $1880.3^{\mathrm{a}} \pm 70.9$ \\
Spring & $552.7^{\mathrm{ab}} \pm 15.1$ & $1067.8^{\mathrm{a}} \pm 34.4$ & $1351.8^{\mathrm{ab}} \pm 45.6$ & $1572.5^{\mathrm{b}} \pm 57.6$
\end{tabular}

${ }^{\mathrm{a}, \mathrm{b}}$ Means on the same row with different superscripts are significantly different.

Table 4. Daily gain (g), feed intake (g) and feed conversion in growing rabbits as affected by seasons (Means \pm SE).

\begin{tabular}{c|c|l|c}
\hline Season & Daily gain $(\mathrm{g})$ & \multicolumn{1}{|c|}{ Feed intake $(\mathrm{g})$} & Feed conversion \\
\hline Summer & $20.69^{\mathrm{b}} \pm 0.71$ & $57.67^{\mathrm{b}} \pm 1.72$ & $3.82 \pm 0.13$ \\
Autumn & $22.88^{\mathrm{b}} \pm 0.83$ & $60.22^{\mathrm{b}} \pm 2.04$ & $3.58 \pm 0.16$ \\
Winter & $28.92^{\mathrm{a}} \pm 0.99$ & $75.39^{\mathrm{a}} \pm 2.5$ & $3.32 \pm 0.19$ \\
Spring & $22.41^{\mathrm{b}} \pm 0.79$ & $67.68^{\mathrm{a}} \pm 2.04$ & $3.85 \pm 0.15$ \\
\hline
\end{tabular}

$\overline{\mathrm{a}, \mathrm{b}}$ Means on the same row with different superscripts are significantly different.

Table 5. Metabolic changes in growing rabbits under different seasons (Means $\pm \mathrm{SE}$ ).

\begin{tabular}{|c|c|c|c|}
\hline Season & $\begin{array}{c}\text { Glucose } \\
(\mathrm{mg} / \mathrm{dl})\end{array}$ & Triglycerides $(\mathrm{mmol} / \mathrm{L})$ & $\begin{array}{c}\text { Urea } \\
(\mathrm{mmol} / \mathrm{L})\end{array}$ \\
\hline Summer & 112.1 & $1.47^{\mathrm{a}}$ & $7.40^{\mathrm{b}}$ \\
\hline Autumn & 112.6 & $1.01^{\mathrm{ab}}$ & $7.33^{\mathrm{b}}$ \\
\hline Winter & 123.7 & $1.15^{\mathrm{ab}}$ & $8.05^{\mathrm{ab}}$ \\
\hline Spring & 107.4 & $0.78^{\mathrm{b}}$ & $0.03^{\mathrm{a}}$ \\
\hline \pm SE & 11.1 & 0.19 & 0.64 \\
\hline
\end{tabular}

a,b Means on the same row with different superscripts are significantly different. 


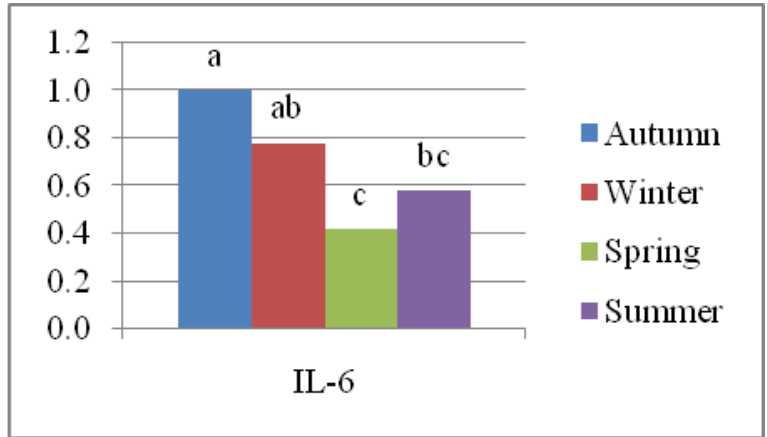

Figure 1: Gene expression of interleukin$6(T L-6)$ in rabbits under different seasons

\section{References}

Abrantes, J., Areal H. \& Esteves,P.J. 2013. Insights into the European rabbit (Oryctolaguscuniculus) innate immune system: genetic diversity of the toll-like receptor 3 (TLR3) in wild populations and domestic breeds. (). BMC Genetics, 14:73

Amici, A., Canganella F., Bevilacqua, L. 1998. Effects of high ambient temperature in rabbits: metabolic changes, caecal fermentation and bacterial flora. World Rabbit Science, vol.6, 319324.

Ayoub, M. A. Okab, A. B. \& Koriem, A. A. 2007. Effect of seasonal variations on some hematological and plasma biochemical parameters in Egyptian male and female baladi rabbits. The $7^{\text {th }}$ inter. Conf .on Rabbit Prod. In Hot Clim., Ghourdaga, Egypt, 6-9 December, 2007, p. 509522.

DalleZotte, A. \& Paci, G. 2013. Influence of Rabbit Sire Genetic Origin, Season of Birth and Parity Order on Doe and Litter Performance in an Organic Production System Asian-Aust. J. Anim. Sci. 26:43-49.

El-Sabrout, K., El-Seedy, A. Shebl, M.K. Soliman, F.N.K. \& El-Sebai, A. 2014. Molecular markers and productive performance relations for line $\mathrm{V}$ and Alexandria rabbitsunder Egyptian environmental conditions. Inter. J. Life Sci. Biotechn.Pharm. Res., 3: 345-361.

Hanaa A., El-Raffa, A., Shebl, El-Delebshany, M.K A. \& El-Sayed, N. 2014. Genetic evaluation of some economic traits in a maternal line of rabbits. Egypt. J. Poult. Sci., 34: 85-98.

Hassan, N.S., El-Tawil, E.A. Karima, S. \& Gad. H.A.M. 1994. Performance of New Zealand White does as affected by different environmental factors. Cahiers Options Mediterraneenns, $1^{\text {st }}$ International Conference of Rabbit Production in Hot Climate, Cairo, Egypt. 8: 271-278.

Kajikawa, O., Frevert, C.W., Lin, S.M., Goodman, R.B., Mongovin, S.M., Wong, V., Ballman, K., Daubeuf B., Elson, G.\& Martin, TR. 2005. Gene

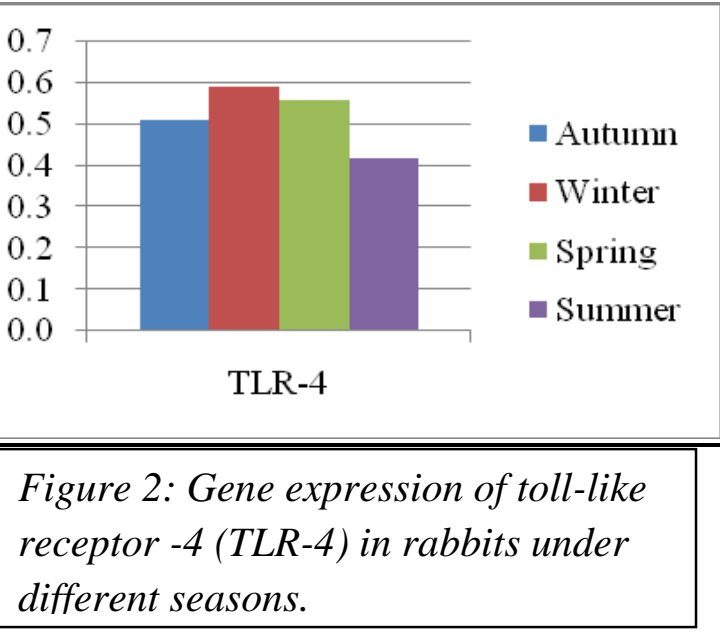

expression of Toll-like receptor-2, Toll-like receptor-4, and MD2 is differentially regulated in rabbits with Escherichia coli pneumonia. Gene, 344, 193-202.

Kulcsár, G., Fábián, K., Farsang, A. \& Virág, Gy. 2008. Evaluation of the protection provided by an inactivated trivalent Pasteurella Multocida vaccine against experimental Pasteurella infection and Pasteurellosis in commercial environment. $9^{\text {th }}$ World Rabbit Congress - June 10-13, 2008 Verona - Italy, p 987-992.

Mann, D.L. 2003. Stress activated cytokines and the heart. Ann. Rev. Physiol., 65: 81-101.

Moscati, L., Dal Bosco, A., Battistacci, L., Cardinali, R., Mugnai ,C. \& Castellini, C.2008. Native immunity and oxidative traits of growing rabbits. World Rabbit Sci., 16: 213 - 220.

Okab, A. B., El-Banna, S.G., \& Koriem, A. A. 2008. Influence of environmental temperatures on some Physiological and Biochemical Parameters of New-Zealand Rabbit males. Slovak J. Anim. Sci., 41, (1): 12 - 19

Poujardieu, B., \& Matheron, G. 1984. Influence d'une ambiance chaudeethumidesur la croissance de futures reproductrices. $3^{\text {rd }}$ World Rabbit Congress, Rome, I: 107-118.

Reddy, J.K.,\& Rao, M.S.,2006 Lipid metabolism and liver inflammation. II. Fatty liver disease and fatty acid oxidation. Am.J. physiol. Gastrointest. Liver Physiol. 2006; 290, 852-858.

Romijn, J.A., Coyle, E.F., Sidossis, L.S., Zhang, X.J., \& Wolfe, R.R. 1995. Relationship between fatty acid delivery and fatty acid oxidation during strenuous exercise. J. Applied Physiol., 79:19391945.

SAS, 1999. SAS user'sguide: Statistical Analysis System Institute, inc. Cary, N.C.

Schnupf, P. \& Sansonetti P. J. 2012 Quantitative RTPCR profiling of the Rabbit Immune Response: Assessment of Acute Shigellaflexneri Infection. PLoS One, 7(6): e36446.

Tuvdendorj, D., Zhang, X. Chinkes, D. L. Wang, L., Wu Z., Rodriguez, N. A. Herndon, D. N. \& Wolfe 
R.R. 2015. Triglycerides produced in the livers of fasting rabbits are predominantly stored as opposed to secreted into the plasma. Metabolism, 64(5): 580-587.

Vassault, A. 1986. Protocol de validation des techniques. Ann Biol Clin. ;44: 686-745.
Yki-Järvinen ,H. 2010. Liver fat in the pathogenesis of insulin resistance and type 2 diabetes. Dig Dis., 28:203-209.

Yuan, J.S., Reed, A., Chen, F. \& Stewart, C.N. 2006. Statistical analysis of real-time PCR data. BMC Bioinformatics, Feb 22;7:85. 


\section{تأثير الموسم على النمو و التمثيل الغذائى والاستجابة المناعية في الأرانب}

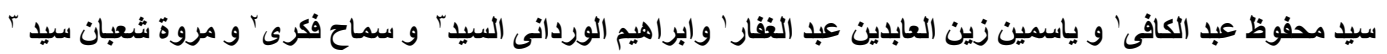

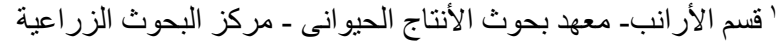

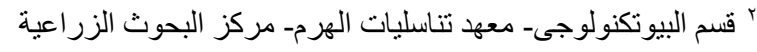

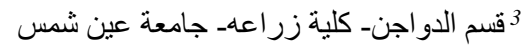

أجريت الدر اسة الحالية لدر اسة تأثثر الموسم على أداء النمو و مقاييس التثنيل الغذائى والتعبير الجيني للمناعة الاساسية والأستجابة للتلقيح ضد لقاح

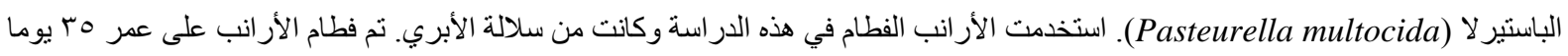

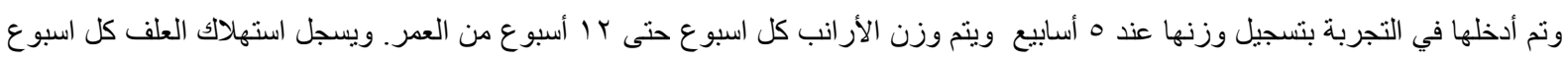

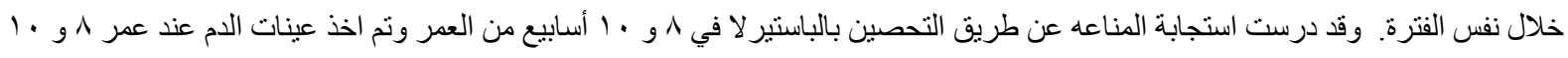
و r أسبو عا. تم قياس التعبير الجينى لجين Interleukin-6 و جين Toll like receptor-4 بو اسطة تقنية الـ Real Time-PCR.

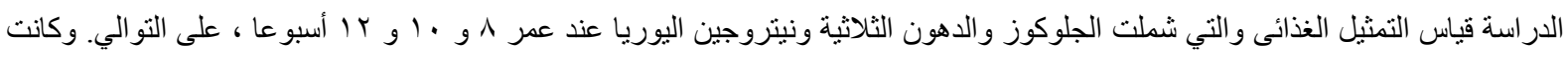

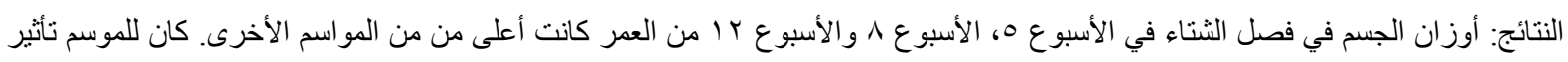

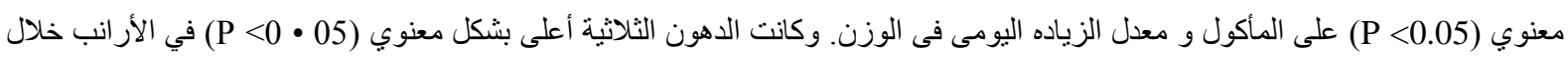

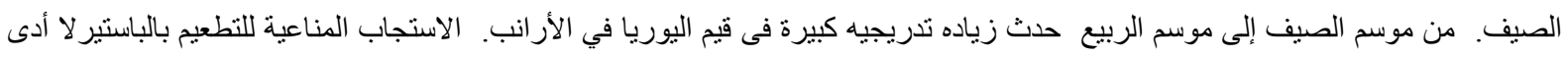

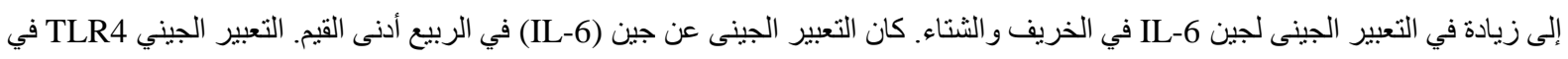

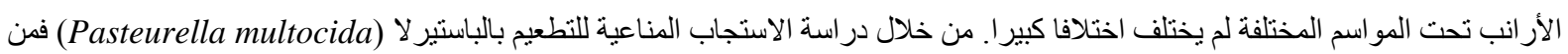
الافضل استخدام إضافات لتعزيز المناعة خلال فصلى الصيف والربيع في الأرنب. 